\section{AGRICULTURAL EDUCATION ASSOCIATION}

\section{SUMMER CONFERENCE}

$\mathrm{A}^{\mathrm{T}}$ T the summer conference of the Agricultural Education Association held at the University of Reading on July 8 and 9, the chief topic for dis. cussion was the Report of the Luxmoore Committee on Post-War Agricultural Education. Lord Justice Luxmoore himself was to have been the guest of honour at the conference dinner on Thursday evening, but was prevented from attending by ill-health. Mr. W. J. Cumber, who proposed the toast of the Agricultural Education Association in Lord Justice Luxmoore's place, said that science has yet a lot to teach the agriculturalist, and he himself, in going to the institutes, colleges and universities with the Committee, had learned a great many things which were going to be of advantage to him. $\mathrm{He}$ believed in mixing up science with practice, for in that way only would it be possible for British agriculture to compete with the rest of the world.

Three sessions were devoted to discussing the Luxmoore Report, and to facilitate the deliberations a memorandum had been circulated to members asking specific questions. The first question, for example, was: Does the Association agree that compulsory continuation classes should be under the Board of Education? With practically no discussion, members agreed.

The second point was, Should the national authority for voluntary agricultural education be a New National Council; the Ministry of Agriculture with appropriate technical staff; or the Board of Education? There was some difference of opinion on these alternatives, though the last authority did not find a supporter. Regret was expressed that the Committee, in considering the re-organization of agricultural education, had not studied the system operating for many years in the United States. Some members thought that the relationship between the Minister of Agriculture and the proposed new national council had not been made sufficiently clear, while others feared that the report envisaged a system of autocratic, centrally-governed education. Others, however, felt that under the proposed central council some of the financial difficulties of the poorer counties might be solved, while at the same time the agricultural education service as a whole would be given a professional status. Eventually it was unanimously agreed that it should be the statutory duty of a competent central body to ensure that adequate agricultural education is provided throughout Great Britain; by a five to one majority, the proposed new National Council was approved as the national authority for voluntary agricultural education.

There was an interesting debate about the desirability of local advisory committees having executive powers, the general feeling being that it would not be possible to get together or hold together the best men on committees that are purely advisory. The desirability of each county initiating the scheme of education best suited to it, rather than having a central scheme forced upon it, was also stressed, and the meeting passed a resolution that the National Council should work through new committees with executive powers to initiate and carry out approved schemes of agricultural education.

With egard to the specialist advisory service, it was suggested that certain of the science subjects, such as mycology and entomology, are not of sufficient economic importance to justify specialist advisers, and that there should be provision for advisory officers in the broader subjects such as botany, grassland, animal husbandry and plant husbandry. American experience was quoted on this matter, and after further debate it was agreed that the present classification by sciences is unsatisfactory and inadequate, and that attention be directed to the need for re-grouping in order to cover the whole field of agriculture.

The conference was unanimous in deploring the proposed separation of the teaching and advisory services, which would seriously impair the efficiency and usefulness of both, and it did not agree with the drastic reduction in the number of provinces recommended in the Luxmoore Report. It also concluded that the unification of the advisory work of the county organizer and that of the specialist provincial advisers. would not be easily secured under a provincial administrator, and it re-aifirmed the principle laid down in the evidence submitted by the Associa. tion to the Luxmoore Committee, namely, that "it is the opinion of the Association that for the efficiency of advisory work all local organizers and specialist advisory officers should be members of one organisation, but this opinion is expressed without prejudice to the opinions held by members about the best administrative means of effecting such unification".

The conference then proceeded to discuss in detail the proposals of the Luxmoore Committee regarding farm institutes, agricultural colleges and university departments of agriculture, taking the paragraphs as set out in the Report. Many of these paragraphs were accepted without debate, but on others there was a useful exchange of opinions which considerations of space make it impossible to report adequately. A fuller account will appear in the Association's journal Agricultural Progress. It is interesting to note, however, that there was general condemnation of the national diploma in agriculture.

During the three sessions, the conference was very greatly helped by the contributions of Mr. R. Fde, secretary of the Luxmoore Committee, whose explanations and general assistance were much appreciated by members of the Association.

Turning now to the formal papers, there were two of outstanding educational interest. The first was a description of the progress of grassland research in the United States by Prof. D. B. Johnstone-Wallace, who has returned to Great Britain on special leave after fourteen years as agrostologist and professor at Cornell University. Grassland research in the United States is a comparatively recent development ; Prof. Johnstone-Wallace found that there was very little work being done on pasture improvement when he made his first tours in the eastern States during 1929 and 1930. Since then, the importance of phosphorus and nitrogen have been recognized, and the high value of wild white clover has been amply demonstrated. Detailed examination of strains of herbage plants from all parts of the world have been carried out, and it has been found that Kentucky blue grass (Poa pratensis), creeping red fescue, and certain types of timothy and cocksfoot, together with wild white clover, are the most useful species for general use. Much is expected from bird's foot trefoil, which has been found to possess drought-resisting properties of a high order. For silage purposes a combination of Ladino clover (a giant species of white clover) and 
Aberystwyth "mop" cocksfoot has given exceptionally good results.

An interesting development in the pasture work at Cornell is the detailed examination of the movements of grazing animals, during which the actions of beef cows are accurately recorded throughout complete periods of 24 hours. It had been found that a cow grazes only 8 hours daily, lies down 12 hours, 'stands about' 4 hours, and chews the cud 7 hours. It walks about $2 \frac{1}{2}$ miles a day, drinks water only once, and grazes to within half an inch of the ground surface. It prefers herbage that is four to five inches long, and if the grass grows longer than this its consumption falls off. Altogether, this piece of research provides a remarkable confirmation of the value of rotational grazing.

The second paper dealt with the organization of agricultural education in the United States, and was given by Prof. R. Rae, of the University of Reading, who recently made a tour of the principal agricultural colleges in America. In general, the American system resembles that in Britain, for the activities of each centre fall into three main sections, teaching, experiment or research, and extension service. Prof. Rae, however, was very favourably impressed with the way in which all the various agricultural services, both State and Federal, are grouped together in the same town, and he believes that Great Britain might well give serious consideration to this point when considering post-war organization. Equipment for teaching purposes is on a much larger and more generous scale than we have ever aspired to ; some of the examples quoted by Prof. Rae left no doubt in the minds of his audience on this point.

Extension work was described as "the educational arm of agriculture in the United States. It is a co-operative project between Federal, State and local governments, and private groups of farmers and people. ... It has a large number of local unpaid volunteer leaders consisting of farmers and farmers' wives, and a relatively small paid staff". These extension services combine in America the fields of work covered in Great Britain by the advisory service and the county agricultural staff. From Prof. Rae's paper, however, one got the impression that it goes further than the British system; for example, there are more than a million volunteer neighbourhood extension leaders organized into a system whereby the Government can reach every farm family with important information on measures necessary in connexion with the War, while "through doing, and leading others, the rural man, woman or youth who takes part in extension work experiences a change in his or her person. This change is one that builds ability and greater confidence in self and future".

\section{PEOPLES OF NEW GUINEA}

T HE ninth of the Smithsonian War Background Studies series deals with New Guinea*, that fascinating island which lies to the north of Australia and has been so much in the public eye since Japan entered the War. With its central backbone of high mountains and its coastal areas of swamp or coral reef, it is an island of great contrasts, while the dis-

- Smithsonian Institution. War Background Studies, No. 9 : The Native Peoples of New Guinea. By M. W. Stirling. (Publication 3726.) Pp. vi $+25+28$ plates. (Washington, D.C. : Smithsonian Institution, 1943.) covery of gold in the interior proved a notable addition to the valuable traffic in bird of paradise plumes-now forbidden. The island is divided into three portions, the westerly administered by the Netherlands, the south-east by Australia and the north-east, formerly German, also by Australia under a mandate. Owing to the difficulty of travel, which was done for the most part by rivers, the interior remained only partially explored until recently when air transport to the goldfields opened up a great deal of the interior.

The natives are of three main stocks, the Negritos in the northern mountains, the Papuans and the immigrants from Melanesia; there has, naturally, been a lot of inter-marrying, but the three groups are easily distinguishable. The Negritos are a small woolly-haired people found at certain spots along the central range, living still in the stone age, and with bows and arrows and a deadly stone axe as weapons. They are on the whole a friendly and cheerful people and presumably the earliest human inhabitants. The Papuans, who also arrived in the island at an early date, are the characteristic racial stock and are a bigger race than the Negritos ; they are dark-skinned, woolly-haired and inclined to be bearded. They occupy most of the interior of the island and all the west and south-western coastal region from Geelvink bay to the Gulf of Papua, as well as other scattered areas. Although they practise a certain amount of simple cultivation, they are more typically hunting and fishing folk with a strong tendency towards cannibalism, headhunting and fighting in general. The Melanesians-the latest arrivals-are found around the east, north-east and south-east coasts and are a lighter-skinned race with hair that may be frizzy or wavy. (The author's statement that they are dark-skinned and woolly-haired does not tally with the descriptions by Seligman and other authorities.) They are a sea-going folk with fine outrigger or double canoes and are of a more cheerful dis. position than the often morose Papuans.

It is a pity that some photographs of these attrac. tive people and their culture in the south-east could not have been included in this publication, instead of the illustrations being confined to Netherlands New Guinea.

K. RISHBETH.

\section{EDUCATION IN THE ARMY}

$\mathrm{D}$ URING the winter of 1942-43 Dr. S. J. Curtis acted as chief instructor at the various courses of army education held at the Univer. sity of Leeds. The courses were designed to be of assistance to regimental instructors who, on returning to their units, were invited to lecture and introduce discussions and in other ways promote the growth of the war-time scheme for education in the Army. As the courses proceeded it was recognized that a useful purpose would be attained by providing the instructors with information about the institution to which they owed allegiance, the British Army. Most soldiers have some knowledge of their particular regiment, but many are unfamiliar with the regiment's place in the general background of the Army. Dr. Curtis' excellent little volume ${ }^{1}$ has been prepared to meet the deficiency. The soldiers who read it will scarcely avoid feeling a legitimate pride as members of an organization whose proud record is still unfolding. "The Story of the British Army" should find its way to every unit library and would still reward the 